\title{
Cross-Feeding Among Soil Bacterial Populations: Selection and Characterization of Potential Bio-inoculants
}

\author{
Valéria Maria Araujo Silva ${ }^{1}$, Claudia Miranda Martins ${ }^{1}$, Fernando Gouveia Cavalcante ${ }^{1}$, Karoline Alves Ramos ${ }^{1}$, \\ Leandro Lopes da Silva ${ }^{1}$, Francisca Gleire Rodrigues de Menezes ${ }^{1}$, Rogério Parentoni Martins ${ }^{1}$ \\ $\&$ Suzana Cláudia Silveira Martins ${ }^{1}$ \\ ${ }^{1}$ Federal University of Ceará, Fortaleza, CE, Brazil \\ Correspondence: Suzana Cláudia Silveira Martins, Federal University of Ceara, Fortaleza, CE, Brazil. E-mail: \\ suzanac@ufc.br
}

Received: January 28, 2019

Accepted: March 2, 2019 Online Published: April 15, 2019

doi:10.5539/jas.v11n5p23

URL: https://doi.org/10.5539/jas.v11n5p23

\begin{abstract}
The biological nitrogen fixation constitutes a strategy to accelerate soil reclamation and the symbiotic systems Rhizobium-legume is the major $\mathrm{N}_{2}$-fixing in which the enzyme carboxymethyl cellulase plays a key role. As many rhizobia species are cellulase negative, the association with cellulolytic bacteria can be a strategy for the recovery of degraded ecosystems. It has been hypothesized that the sharing of resources should mostly be prevalent among phylogenetically and metabolically different species. Accordingly, twenty-seven actinobacteria isolates from Actinobacteria phyla and twenty-six rhizobia isolates from Proteobacteria phyla were selected from the bacterial collection of the Laboratory of Environmental Microbiology of the Federal University of Ceará. The presence of cellulolytic activity was observed for the rhizobia isolates at $28{ }^{\circ} \mathrm{C}$ and for actinobacteria isolates at $28,39,41,43$ and $45{ }^{\circ} \mathrm{C}$. Rhizobia isolates deficient in cellulase and actinobacteria isolates with enzymatic activity detected at higher temperature were selected and characterized. The antagonism between isolates of two groups was tested and the pairs antagonistic were eliminated. The cross-feeding test between actinobacteria and rhizobia isolates was realized in a chemically defined medium containing carboxymethyl-cellulose as the only carbon and energy source. Growth of rhizobia strains in $50 \%$ of the pairwise indicated that the cellulose hydrolyzed by actinobacteria was used as substrate for the growth of the rhizobia. The Bradyrhizobium strain R10 associated with Streptomyces strains A09 and A18 and Nocardia A11 are promissory inoculants for recovery of semi-arid regions.
\end{abstract}

Keywords: metabolic interactions, revegetation, actinobacteria, rhizobia, semiarid region

\section{Introduction}

Semiarid environments are characterized by high temperatures, low water availability, high salinity and low nutrient content in the soil which may be attributed to low nitrogen fixing activity (Divito \& Sadras, 2014).

Brazil has one of the largest semi-arid areas in the world (about 1 million $\mathrm{km}^{2}$ ) and about $94 \%$ of this region is characterized as having moderate to high susceptibility to desertification resulting from the climatic variations and human activities (Vieira et al., 2015).

Cowpea (Vigna unguiculata (L) Walp) is a typical legume of the Brazilian northeast because of its adaptability to severe climatic conditions. The root of this plant is nodulated by a bacterial group generically known as rhizobia (Zilli, Valisheski, Freire Filho, Neves, \& Rumjanek, 2004), classified in the Proteobacteria phyla and that act as the primary symbiotic fixer of nitrogen (Seishiro, Motomi, \& Wataru, 2013).

Nitrogen fixation is energetically an expensive process, dependent on the available energy from plant residues that contain a high percentage of cellulose. For this reason, the production of cellulolytic enzymes has been considered an indirect mechanism to promote plant growth (Gupta, Parihar, Ahirwar, Snehi, \& Singh, 2015). Furthermore, the establishment of rhizobia within legume root nodules requires the disruption of the plant cellular wall (Robledo et al., 2008) and the carboxymethyl cellulase (CMCase) is the enzyme used to establish this symbiosis (Chen, Wei, Chang, \& Lin, 2004). However, the cellulolytic activity of rhizobia is very low and there are few species that can fix nitrogen $(\mathrm{N})$ and also use cellulose as their main energy and carbon source (Jiménez-Zurdo, Mateos, Dazzo, \& Martínez-Molina, 1996). 
Biological nitrogen fixation in arid and semiarid areas is influenced by the higher soil temperatures (Alexandre \& Oliveira, 2013). The areas are deficient in soluble phosphorous (Sinaj et al., 2001) and characterized by the presence of antibiotics substances (Naamala, Jaiswal, \& Dakora, 2016). Bacterial species nitrogen fixing differ in their tolerance to main environmental stresses (Graham, 1992), therefore, the screening of indigenous strains is imperative for decreasing soil loss and ameliorating adverse edaphic conditions.

Among the bacterial soil population, the Actinobacteria constitute one of the largest phyla and represents the most abundant phylum in the Brazilian northeastern semiarid region (Kavamura et al., 2013). This bacterial group produces an extensive range of bioactive molecules such as cellulases (Saini, Aggarwal, Sharma, \& Yadav, 2015), and also substances active against other microorganisms (Lima, Martins, Siqueira, Soares, \& Martins, 2017).

A process that governs the growth and composition of the microbial ecosystem is the cross-feeding that involves the metabolic cooperation between microorganisms in partnerships allowing accessing substrates that neither microorganism could metabolize alone (Seth \& Taga, 2014; D'Souza et al., 2018). In ecological terms, cross-feeding is a type of facilitation where one organism makes the environment more suitable for another (Bronstein, 2009). In nature, bacterial competition for resources is common, but positive interactions among bacteria also occur, especially during the degradation of complex substrates (Wintermute \& Silver, 2010). Thus, in a cooperative process in which cellulolytic and nitrogen-fixing microbiota coexist, the cellulose breakdown continues without further depletion of nitrogen and both types are benefited by this process. So, co-inoculation of leguminous plants with cellulolytic actinobacteria and rhizobia is a strategy to enhance nitrogen fixation contributing to revegetation and recuperation of desertified soil. The use of native species is recommended because these bacteria adapt to the specific environmental conditions, which facilitates their survival and the successful nodulation of the host plant (Koskey et al., 2017).

Although association of actinobacterial and rhizobial strains has been described as promoting plant growth (Soe et al. (2012), Htwe and Yamakawa (2015), Soe and Yamakawa (2016), Htwe et al. (2018a, 2018b), studies involving cross-feeding between these two groups still are rare, especially in arid and semi-arid environments. Moreover, studies with bacteria isolated from the same environment, maximize resemblance to the natural community and preserves indigenous interactions shaped by co-adaptation/evolution (Stadie, Gulitz, Ehrmann, \& Vogel, 2013).

Based on the above, this work aimed to evaluate in vitro the metabolic compatibility between strains of actinobacteria and rhizobia isolated from soil in the Brazilian semiarid for selection of potential bioinoculants.

\section{Material and Methods}

This study was approved by the Institute for Biodiversity Conservation (ICMBio) in accordance with Brazilian law (Permit Number: SISBIO38980-3).

The bacterial isolates used ( 26 rhizobia and 27 actinobacteria) were maintained in the cultural collection of the Laboratory of Environmental Microbiology of the Federal University of Ceará (UFC). They were isolated from soil samples collected in the period of August 20-24, 2012 in Ubajara National Park (UNP), a protected environmental area on the Ibiapaba plateau in northern Ceará, Brazil. The Park is centered at latitude $3^{\circ} 46^{\prime} \mathrm{S}$ and longitude $40^{\circ} 54^{\prime} \mathrm{W}$, with altitudes ranging from 800 to $1100 \mathrm{~m}$ above sea level (Cunha \& Araújo, 2014) and two distinct climate periods: the first half of the year, cooler and wetter, and the second half, hot with virtually no rainfall (IBAMA, 2006).

Rhizobia isolates were captured using cowpea [Vigna unguiculata (L.) Walp.] as bait plant and the nodules macerated in agar medium mannitol yeast extract (YMA) (Vincent, 1970). The isolates in which were observed nodules root and the red color were authenticated by planting and inoculation in jars of $300 \mathrm{~mL}$ with cowpea (Torres-Júnior et al., 2014). The actinobacteria were isolated in casein dextrose agar (CDA) (Clark, 1965) and the isolates from the two groups were reactivated in the same liquid culture media and inoculated in Petri dishes to verify the purity.

The actinobacteria and rhizobia isolates were inoculated separately in culture medium containing carboxymethylcellulose as only source of carbon and energy. The rhizobia isolates were incubated at $28 \pm 2{ }^{\circ} \mathrm{C}$ for 10 days and actinobacteria isolates were incubated at $28,39,41,43$ and $45{ }^{\circ} \mathrm{C}$ to determine the effect of temperature on the enzyme activity. After incubation, Congo red solution was added to each plate and left at rest for 15 minutes at $26^{\circ} \mathrm{C}$. Thereafter, the excess solution was drained and $10 \mathrm{ml}$ of $\mathrm{NaCl}$ solution $(2 \mathrm{M})$ was added to each dish and left at rest for 30 minutes at $26^{\circ} \mathrm{C}$. The presence of hydrolysis zones around colonies was registered as a positive response (Hankin \& Anagnostakis, 1977). Each experiment was carried out 
independently by taking four replicates with two repetitions. Non-cellulolytic rhizobia isolates and actinobactéria isolates with enzymatic activity at more elevated temperature were selected to cross-feeding test.

To discard possible antagonism between selected actinobacteria and rhizobia isolates each actinobacteria was inoculated with each one of the rhizobia isolates. Accordingly, the plates were incubated for 5 days at $28{ }^{\circ} \mathrm{C}$ and inhibitory activity was confirmed by the appearance of a clear zone (inhibition zone) extending from the colony of the actinobacteria to the rhizobia growth border (Lima et al., 2017). The pairwise in which actinobacteria isolate inhibited the rhizobia isolate were discarded. All tests were performed in triplicate with three repetitions.

The cultural characterization of the cellulolytic actinobactéria selected was performed by observation of the aerial and reverse mycelium with the use of a color chart (Wink, 2012). Morphological characterization was carried out by micro cultivation under a Zeiss light microscope at 1000 magnification and for the production of melanin the strains were grown in medium with and without tyrosine (Lima et al., 2017). Tolerance to $\mathrm{pH}(4,5,6$, 7, 8 and 9), sodium chloride $\left(0,5,10,20,25\right.$ and $\left.35 \mathrm{~g} \mathrm{~L}^{-1}\right)$ and temperature $\left(41,43\right.$ and $\left.45{ }^{\circ} \mathrm{C}\right)$ was evaluated using the CDA culture medium (Priyadarshini et al., 2016). Moreover, the use of carbon sources (arabinose, sucrose, xylose, inositol, mannitol, fructose, rhamnose, raffinose), with glucose (positive control) and water (negative control) (Shirling \& Gottlieb, 1966) and nitrogen sources (potassium nitrate, L-histidine, Arginine) using as positive control (L-asparagine) and medium without nitrogen as negative control (Basak \& Majumdar, 1973) were determined. Production of lipase (Sierra, 1957) amylase (Tole, Fawade, \& Patil, 2016) and xylanase (Tasia \& Melliawati, 2017) was evaluated in culture medium containing the inducers Tween 80 , starch and xylan, respectively.

Non-cellulolytic Rhizobia isolates were analyzed using morph-cultural characteristics (growth rate, color and slime production) and resistance to antibiotics Amikacin (AMI 30), Amoxicillin (AMC 30), Ampicillin (AMP10), Aztreonam (ATM 30), Cephalothin (CFL 30), Cefepime (CPM 30), Cefoxitin (CFO 30), Ceftadizime (CAZ 30), Ceftriaxone (CRO 30), Ciprofloxacin (CIP 05), Chloramphenicol (CLO 30), Gentamycin (GEN 10), Piperacillin (PIT 110) and Tetracycline (TET 30) (Mueller, Skipper, Shipe, Grimes, \& Wagner, 1988). Moreover, the use of carbon sources (sucrose, glucose, arabinose, rhamnose, fructose and xylose), amylase, and phosphate solubilization were determined according to Shirling and Gottlieb (1966), Tole et al (2016) and Pikovskaya (1948), respectively. Tolerance to sodium chloride $\left(0,5,10,20,30,40\right.$ and $\left.50 \mathrm{~g} \mathrm{~L}^{-1}\right), \mathrm{pH}(4$ and 10$)$ and temperature $\left(39,41,43\right.$ and $45{ }^{\circ} \mathrm{C}$ ) was performed in YMA medium (Kulkarni \& Nautiyal, 2000). The strains BR 3486 (Burkholderia phymatum), INPA 03-11B-Bradyrhizobium sp. (BR 3301), UFLA 03-84-Bradyrhizobium sp (BR 3302), BR 3267 (Bradyrhizobium sp.), BR 3262 (Bradyrhizobium sp.), BR 2003, and BR 2801 (Bradyrhizobium elkanii) were used as references.

For the selection of the most promising rhizobia isolates for each characteristic evaluated was established a range of values of 0-5 in the total maximum of 22 scores (Table 1).

Table 1. Scores for phenotypic characteristics of rhizobia isolates

\begin{tabular}{|c|c|c|c|c|c|c|c|c|c|c|c|c|c|}
\hline Rate growth & Score & $\begin{array}{l}\text { Temperature } \\
\left({ }^{\circ} \mathrm{C}\right)\end{array}$ & Score & $\begin{array}{l}\mathrm{NaCl} \\
\left(\mathrm{g} \mathrm{L}^{-1}\right) \\
\end{array}$ & Score & $\begin{array}{l}\text { No. of } \\
\text { Antibiotics }\end{array}$ & Score & $\begin{array}{l}\text { Carbon } \\
\text { sources }\end{array}$ & Score & $\begin{array}{l}\text { Phosphorous } \\
\text { solubilization }\end{array}$ & Score & $\mathrm{pH}$ & Score \\
\hline Slow & 0 & $<39$ & 1 & $<10$ & 0 & 0 & 0 & 0 & 0 & + & 1 & 4 & 1 \\
\hline Fast & 1 & 39 & 2 & 10 & 1 & 01-03 & 1 & $1-3$ & 1 & - & 0 & 10 & 1 \\
\hline- & & 41 & 3 & 20 & 2 & 04-06 & 2 & 4-6 & 2 & - & - & - & - \\
\hline- & & 43 & 4 & 30 & 3 & 07-09 & 3 & $7-9$ & 3 & - & - & - & - \\
\hline- & & 45 & 5 & 40 & 4 & $10-12$ & 4 & - & - & - & - & - & - \\
\hline- & & - & - & 50 & 5 & $13-14$ & 5 & - & - & - & - & - & - \\
\hline
\end{tabular}

Molecular characterization of cellulolytic actinobacteria and non-cellulolytic rhizobia isolates was partially performed (Pereira, Ibanez, Rosenblueth, Etcheverry, \& Martinez-Romero, 2011).

Cross-feeding assay was realized according to Cuesta et al. (2012) with modifications. In the experimental design each rhizobial strain deficient for the production of cellulase was paired with an actinobacteria strain still capable of producing cellulase at the highest temperature tested. Accordingly, actinobacteria strains were inoculated separately in carboxymethylcellulose agar in the form of spots and incubated at $28 \pm 2{ }^{\circ} \mathrm{C}$ for 10 days. After, one milliliter of culture of each rhizobia isolate previously cultivated in YM medium for seven days, was transferred to micro tubes with a capacity of $1.5 \mathrm{~mL}$, centrifuged at $12,000 \mathrm{rpm}$ for 10 minutes, and the precipitate resuspended two times. A droplet of each purified rhizobia culture was distributed around each colony of actinobacteria at a distance of 0.5 to $2.0 \mathrm{~cm}$. The growth of rhizobia strains closer to the actinobacteria was the 
parameter to diagnose for the occurrence of positive metabolic interaction. Moreover, the assay was performed in duplicate with two repetitions.

Compatibility Index was calculated as the number of compatible pairs detected divided by all possible pairwise interactions.

$\mathrm{CI}=\mathrm{n}^{\circ}$ of compatible pairs/all pairwise interactions.

\section{Results and Discussion}

In the present work, at $28^{\circ} \mathrm{C}, 18$ over $27(66.7 \%)$ of the actinobacteria isolates presented cellulolytic activity but, at $39{ }^{\circ} \mathrm{C}$ only $7(25.9 \%)$ isolates were still positive, at $41{ }^{\circ} \mathrm{C}$ six of the seven isolates maintained this characteristic and at $43{ }^{\circ} \mathrm{C}$ and $45^{\circ} \mathrm{C}$ none isolate produced cellulase. Thus, the actinobacteria isolates A06, A09, A11, A12, A13 and A18 were selected for posterior cross feeding test with rhizobia isolates cellulase negative. These isolates were amylase and lipase positive, xylanase negative and able to use all carbon and nitrogen sources tested. The isolates tolerated the maximum temperature evaluated $\left(45^{\circ} \mathrm{C}\right)$, and sodium chloride concentration of $35 \mathrm{~g} \mathrm{~L}^{-1}$. Except A12 that did not tolerate the $\mathrm{pH} 4$ and 9, the others were able to develop in these extreme values. The isolates were identified on the basis of morphological characteristics (Table 2) and the A18 confirmed the identification on the basis of genotypic characteristics.

Table 2. Morphological features of spore chains and aerial and reverse mycelium of the actinobacteria isolates producers of cellulase at $41^{\circ} \mathrm{C}$ and the identification at the genus level (Shirling \& Gottlieb, 1966)

\begin{tabular}{|c|c|c|c|c|c|}
\hline \multirow{2}{*}{ Actinobacterial Isolates } & \multirow{2}{*}{ Morphology } & \multicolumn{2}{|c|}{ Color } & \multirow{2}{*}{ Melanin } & \multirow{2}{*}{ Genus } \\
\hline & & Aerial mycelium & Reverse pigments & & \\
\hline A06 & Spiral spore chain & Cream & Cream & $(-)$ & Streptomyces \\
\hline $\mathrm{A} 09, \mathrm{~A} 18$ & Spiral spore chain & Brown & Gray & $(+)$ & Streptomyces \\
\hline $\mathrm{A} 11, \mathrm{~A} 12, \mathrm{~A} 13$ & Short straight spore chain & Brown & Blue & $(+)$ & Nocardia \\
\hline
\end{tabular}

With respect to rhizobia only three isolates grew in the medium supplemented with carboxymethylcellulose, and twenty-three isolates $(88.4 \%)$ were unable to grow, confirming the inability of this bacterial group to degrade cellulose (Jiménez-Zurdo et al., 1996).

The results of antagonistic activity of the selected cellulolytic actinobacteria isolates on the growth of 23 rhizobia strains deficient in the production of cellulase (118 pairwise combinations) showed that the growth of rhizobia isolates was inhibited only in 14 pairs (Table 3), corresponding to $11.9 \%$. These results confirm that antagonism should mostly be prevalent among phylogenetically and metabolically similar species (Russel, Røder, Madsen, Burmøllea, \& Sørensen, 2017). In addition, as these bacteria were isolated from the same environment, they were presumed to have interacted with each other in the soil and over time promoting coexistence between these groups. The fourteen antagonistic pairwise (Table 3) were eliminated from further cross-feeding test.

Table 3. Antagonism among strains of actinobactéria and of rhizobia isolates from Brazilian semiarid

\begin{tabular}{lllllll}
\hline \multirow{2}{*}{ Actinobactéria isolates } & \multicolumn{7}{c}{ Rhizobia isolates } \\
\cline { 2 - 7 } & R01 & R03 & R06 & R07 & R11 & R14 \\
\hline A06 & + & + & + & + & - & - \\
A09 & - & - & + & - & - & - \\
A11 & - & - & + & + & + & + \\
A12 & - & - & - & - & - & + \\
A13 & - & - & + & - & + & + \\
A18 & + & - & - & - & - & - \\
\hline
\end{tabular}

Note. (+): presence of antagonistic activity; (-): absence of antagonistic activity.

It is widely accepted that actinobacteria are prolific producers of natural bioactive compounds, such as antibiotics (Tiwari \& Gupta, 2012), and that different rhizobia strains show different degrees of susceptibility (Obaton, 1971), due to genetic variation in target genes and resistance genes acquired through horizontal gene transfer (Bhargava, Murthy, Kumar, \& Rao, 2016). Studies in vitro on the effects of metabolites of five actinobacteria strains on the growth of five rhizobia strains (25 pairwise combinations) showed that the growth 
of rhizobia strains was inhibited in 16 pairs, corresponding to $64 \%$. Antagonism was also observed by Patel (1974) between actinobacteria and 12 strains of rhizobia from soil samples. This author reported that about 23-70\% of the actinobacteria inhibited the rhizobia strains. Van Schreven (1964), Damirgi and Johnson (1966), Foo and Varma (1976), Pugashetti et al. (1992), Pereira (1999), and Gregor (2003) have also described the antagonistic action of actinobacteria on rhizobia. More recently, Rassem and David (2017) tested three isolates of actinobacteria in a dual culture against three rhizobium isolates, out of 9 combinations of antagonistic assay 8 showed that actinobacteria executed an inhibitory effect on growth of rhizobium isolate. The antagonistic effect of 14 actinobacteria on 5 rhizobia obtained from soil samples of the same climatic region of the present work registered that of the 70 pairwise combinations 15 (21.4\%) presented antibiosis (Lima et al., 2017). In this work, the authors isolated the strains of actinobacteria and rhizobia of soil of different regions of Brazilian semiarid, which may explain the higher rate of antagonism towards present study.

Generally, the low rainfall, extremes of temperature, $\mathrm{pH}$ and salinity of the semiarid environs are restraining factors to the growth and activity of the nitrogen-fixing bacteria. Therefore, the selection of native strains with better characteristics may improve the efficiency of process (Marulanda, Porcel, Barea, \& Azcon, 2007; Marulanda, Barea, \& Azcon, 2009). In this perspective, non-cellulolytic rhizobia isolates were phenotypically characterized and classified into seven groups (Table 4).

Table 4. Grouping of non-cellulolytic rhizobial isolates according to the phenotypic characteristics

\begin{tabular}{|c|c|c|c|c|c|c|c|c|}
\hline Groups & Isolates & $\mathrm{pH}$ & Growth rate & Mucus & Colony color & $\begin{array}{l}\text { Resistance } \\
\text { (number of of antibiotics) }\end{array}$ & $\begin{array}{l}\mathrm{NaCl} \\
\left(\mathrm{g} \mathrm{L}^{-1}\right)\end{array}$ & $\begin{array}{l}\text { Temperature } \\
\left({ }^{\circ} \mathrm{C}\right)\end{array}$ \\
\hline \multirow[t]{4}{*}{1} & R16 & Acid & Fast & Butyric & Yellow & 1 & 20 & 41 \\
\hline & $\mathrm{R} 21$ & Acid & Fast & Butyric & Yellow & 2 & 10 & 41 \\
\hline & $\mathrm{R} 22$ & Acid & Slow & Butyric & Yellow & 2 & 50 & 41 \\
\hline & R15 Burkholderia sp. (R 15) & Acid & Fast & Butyric & Yellow & 0 & 10 & 41 \\
\hline \multirow[t]{9}{*}{2} & R17 & Acid & Fast & Butyric & White & 1 & 10 & 41 \\
\hline & R19 & Acid & Fast & Butyric & White & 1 & 3 & 41 \\
\hline & $\mathrm{R} 20$ & Acid & Fast & Butyric & White & 2 & 10 & 39 \\
\hline & $\mathrm{R} 23$ & Acid & Fast & Butyric & White & 2 & 10 & 41 \\
\hline & $\mathrm{R} 24$ & Acid & Fast & Butyric & White & 0 & 10 & 41 \\
\hline & $\mathrm{R} 25$ & Acid & Fast & Butyric & White & 0 & 10 & 41 \\
\hline & R05 & Acid & Fast & Butyric & White & 0 & 10 & 39 \\
\hline & R09 & Acid & Fast & Viscous & White & 0 & 10 & 41 \\
\hline & Burkholderia phymatum (BR-3486) & Acid & Fast & Butyric & White & 1 & 10 & 41 \\
\hline 3 & $\mathrm{R} 18$ & Acid & Fast & Butyric & Yellow & 3 & 20 & 45 \\
\hline 4 & $\mathrm{R} 26$ & Acid & Fast & Butyric & Yellow & 2 & 50 & - \\
\hline 5 & R07 & Acid & Slow & Butyric & Yellow & 10 & 30 & 39 \\
\hline \multirow[t]{10}{*}{6} & $\mathrm{R} 01$ & Neut & Slow & Viscous & White & 13 & 3 & - \\
\hline & R03 & Neut & Slow & Viscous & White & 11 & 3 & - \\
\hline & R06 & Neut & Slow & Viscous & White & 12 & 3 & - \\
\hline & R11 Bradhyrhizobium retamae & Neut & Slow & Viscous & White & 11 & 3 & - \\
\hline & $\mathrm{R} 12$ & Neut & Slow & Viscous & White & 12 & 3 & - \\
\hline & R14 Bradhyrhizobium retamae (R11) & Neut & Slow & Butyric & White & 12 & 10 & 39 \\
\hline & Bradyrhizobium sp. (BR 3262) & Acid & Slow & Viscous & White & 13 & 3 & - \\
\hline & Bradyrhizobium sp. (BR-3301) & Acid & Slow & Viscous & White & 11 & 3 & 39 \\
\hline & Bradyrhizobium elkani (BR2801) & Neut & Slow & Viscous & White & 12 & 3 & - \\
\hline & Bradyrhizobium elkani (BR2003) & Neut & Slow & Butyric & White & 9 & 3 & - \\
\hline \multirow[t]{3}{*}{7} & R04 & Alkali & Slow & Viscous & White & 12 & 10 & 45 \\
\hline & $\mathrm{R} 10$ & Alkali & Fast & Viscous & White & 13 & 20 & 45 \\
\hline & Bradyrhizobium spp. (BR-3302) & Acid & Slow & Viscous & White & 14 & 10 & 45 \\
\hline
\end{tabular}

Although the isolates of Group 6 were distinguished by the higher resistance to antibiotics (Resistance $>11$ ), they were less tolerant to high temperatures and to salinity (Table 4), except R14 that tolerate $10 \mathrm{~g} \mathrm{~L}^{-1}$ of NaCl. It 
was also noted that $83 \%$ of the isolates of this group suffered antagonistic effect of selected cellulolytic actinobacteria (Table 3) and all showed slow growth. The R11 isolate was identified on the basis of genotype characteristics as Bradyrhizobium retamae (Table 4), confirming the similarity of the isolates from Group 6 with the utilized reference strains.

The greatest diversity of rhizobia for the use of carbon, ability to solubilize phosphate and grow in extreme $\mathrm{pH}$ were also factors that can positively affected the biological nitrogen fixation (Table 5). The isolated R20 of the Group 2 was the only phosphate solubilizing (Table 5), characteristic very important since the semi-arid soil is deficient in soluble phosphorous in forms of phosphate ion $(\mathrm{P})$.

Moreover, the R15 was identified on the basis of genotype characteristics as Burkholderia sp suggesting that the isolates of the Group 1 can also be identified as of the same genus (Table 4).

Table 5. Biochemical characteristics of non-cellulolytic rhizobial isolates

\begin{tabular}{|c|c|c|c|c|c|c|c|c|c|c|c|c|}
\hline \multirow{2}{*}{ Rhizobia isolates } & \multicolumn{8}{|c|}{ Source of carbon } & \multirow{2}{*}{ Amylase } & \multirow{2}{*}{$\begin{array}{l}\begin{array}{l}\text { Phosphate } \\
\text { solubilizing }\end{array} \\
\end{array}$} & \multicolumn{2}{|c|}{$\mathrm{pH}$} \\
\hline & $\mathrm{Suc}^{1}$ & $\mathrm{Ino}^{2}$ & $\mathrm{Ara}^{3}$ & $\mathrm{Xyl}^{4}$ & $\operatorname{Man}^{5}$ & Fruct $^{6}$ & Rham $^{7}$ & Galac $^{8}$ & & & 4 & 10 \\
\hline R01 & + & + & + & + & + & + & + & + & + & - & + & - \\
\hline R03 & + & + & + & + & + & + & + & + & + & - & + & + \\
\hline R04 & + & + & + & + & + & + & + & + & - & - & + & + \\
\hline R05 & + & + & + & + & + & + & + & + & + & - & + & + \\
\hline R06 & + & + & + & + & + & - & + & + & + & - & + & + \\
\hline R07 & + & + & + & + & + & + & + & + & + & - & - & + \\
\hline R09 & + & + & - & - & + & - & - & - & + & - & + & + \\
\hline R10 & + & + & + & + & + & + & + & + & - & - & - & + \\
\hline R11 & + & + & + & + & + & + & + & + & + & - & + & + \\
\hline $\mathrm{R} 12$ & + & + & + & + & + & + & + & + & + & - & + & + \\
\hline R14 & + & + & + & + & + & + & + & + & + & - & + & + \\
\hline R15 & + & + & + & + & + & + & + & + & - & - & + & + \\
\hline R16 & + & + & + & + & - & + & - & + & - & - & + & + \\
\hline R17 & - & + & - & - & + & + & + & + & - & - & + & - \\
\hline R18 & - & + & - & + & - & - & - & - & + & - & - & + \\
\hline R19 & - & + & - & - & - & - & - & + & + & - & + & + \\
\hline R20 & + & + & + & + & + & + & + & + & + & + & + & + \\
\hline $\mathrm{R} 21$ & - & - & - & - & + & - & + & - & + & - & + & + \\
\hline $\mathrm{R} 22$ & + & + & + & + & + & + & + & + & - & - & + & + \\
\hline R23 & + & + & + & + & + & + & + & + & + & - & + & + \\
\hline R24 & + & + & + & + & + & + & + & + & + & - & + & + \\
\hline R25 & + & + & + & + & + & + & + & + & + & - & + & + \\
\hline R26 & + & + & + & + & + & + & + & + & + & - & + & - \\
\hline
\end{tabular}

Note. ${ }^{1}$ Sucrose $;{ }^{2}$ Inositol $;{ }^{3}$ Arabinose $;{ }^{4}$ Xylose $;{ }^{5}$ Manose; $;{ }^{6}$ Fructose; $;{ }^{7}$ Rhamnose $;{ }^{8}$ Galactose. 
Table 6. Classification of rhizobia isolates according to the values established in the Table 1

\begin{tabular}{|c|c|c|c|c|c|c|c|c|}
\hline Rhizobia & Growth rate & Temperature & $\begin{array}{l}\text { Resistance } \\
\text { antibiotics }\end{array}$ & $\mathrm{NaCl}$ & $\begin{array}{l}\text { Carbon } \\
\text { sources }\end{array}$ & $\begin{array}{l}\text { Phosphate } \\
\text { solubilization }\end{array}$ & $\mathrm{pH}$ & Total \\
\hline \multicolumn{9}{|l|}{ Group 1} \\
\hline R15 & 1 & 3 & 0 & 1 & 3 & 0 & 2 & 10 \\
\hline $\mathrm{R} 16$ & 1 & 3 & 1 & 2 & 2 & 0 & 2 & 11 \\
\hline R21 & 1 & 3 & 1 & 1 & 1 & 0 & 2 & 9 \\
\hline $\mathrm{R} 22$ & 0 & 3 & 1 & 5 & 3 & 0 & 2 & 14 \\
\hline \multicolumn{9}{|l|}{ Group 2} \\
\hline R05 & 1 & 2 & 0 & 1 & 3 & 0 & 2 & 9 \\
\hline R09 & 1 & 3 & 1 & 1 & 2 & 0 & 2 & 10 \\
\hline R17 & 1 & 3 & 1 & 1 & 2 & 0 & 1 & 9 \\
\hline R19 & 1 & 3 & 1 & 0 & 1 & 0 & 2 & 8 \\
\hline R20 & 1 & 2 & 1 & 1 & 3 & 1 & 2 & 11 \\
\hline $\mathrm{R} 23$ & 1 & 3 & 1 & 1 & 3 & 0 & 2 & 11 \\
\hline $\mathrm{R} 24$ & 1 & 3 & 0 & 1 & 3 & 0 & 2 & 10 \\
\hline $\mathrm{R} 25$ & 1 & 3 & 0 & 1 & 3 & 0 & 2 & 10 \\
\hline \multicolumn{9}{|l|}{ Group 3} \\
\hline $\mathrm{R} 18$ & 1 & 5 & 1 & 2 & 1 & 0 & 1 & 11 \\
\hline \multicolumn{9}{|l|}{ Group 4} \\
\hline R26 & 1 & 1 & 1 & 5 & 3 & 0 & 1 & 12 \\
\hline \multicolumn{9}{|l|}{ Group 5} \\
\hline $\mathrm{R} 07$ & 0 & 2 & 4 & 3 & 3 & 0 & 1 & 13 \\
\hline \multicolumn{9}{|l|}{ Group 6} \\
\hline R01 & 0 & 1 & 5 & 0 & 3 & 0 & 1 & 10 \\
\hline R03 & 0 & 1 & 4 & 0 & 3 & 0 & 2 & 10 \\
\hline R06 & 0 & 1 & 4 & 0 & 3 & 0 & 2 & 10 \\
\hline $\mathrm{R} 11$ & 0 & 1 & 4 & 0 & 3 & 0 & 2 & 10 \\
\hline $\mathrm{R} 12$ & 0 & 1 & 4 & 0 & 3 & 0 & 2 & 10 \\
\hline R14 & 0 & 2 & 4 & 1 & 3 & 0 & 2 & 12 \\
\hline \multicolumn{9}{|l|}{ Group 7} \\
\hline R04 & 0 & 5 & 4 & 1 & 3 & 0 & 2 & 15 \\
\hline R10 & 1 & 5 & 5 & 2 & 3 & 0 & 1 & 17 \\
\hline
\end{tabular}

Considering that the maximum score of 22 corresponds to $100 \%$, it was established that the isolates with a percentage greater than or equal to $70 \%$ of the maximum value ( $\geq 15$ scores) would be selected. Thus, the isolates, R04 and R10 of the group 7 (Table 6) were selected for cross-feeding test with cellulolytic actinobacterial strains already selected.

An understanding of microbial metabolism must come from the properties of individual strains in pure culture to the combined interactions of microbial strains in co-culture (Wintermute \& Silver, 2010). Thus, each one of the 6 cellulolytic actinobacterial strains selected was co-cultured with each one of the 2 selected rhizobial strains deficient in the production of this enzyme totaling 12 combinations and 24 experimental units (two repetitions), in quadruplicate.

The Nocardia strains A12 and A13 were incompatible with R04 and R10 Bradyrhizobium strains, while Streptomyces strains A06 and A09 and Nocardia strain A11 were compatible. The Bradyrhizobium strain R10 was compatible with the same strains and also with Streptomyces strain A18 (Figure 1), confirming the hypothesis that phylogenetically and metabolically different bacterial species promote the sharing of resources. 


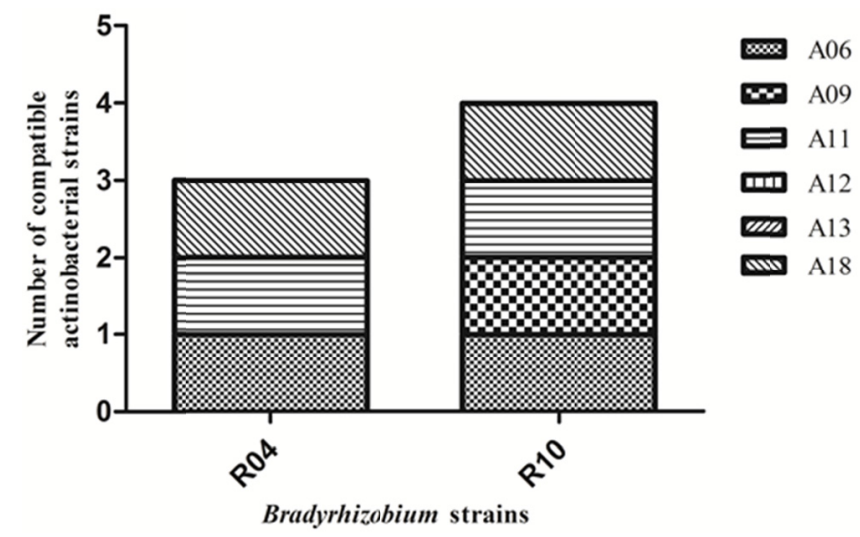

Figure 1. Cross-feeding among Bradyrhizobium strains R04 and R10 and Streptomyces strains (A06, A09 and A18) and Nocardia strains (A11, A12 and A13)

Like this, the compatibility index ( $\mathrm{n}^{\mathrm{o}}$ of compatible pairs/all pairwise interactions) for Bradyrhizobium strains R04 and R10 was 0.5 and 0.7, respectively, confirming the superiority of Bradyrhizobium R10 (Table 6). Thus, the highest index associated with the best performance suggest that, at first instance, the Bradyrhizobium R10 strain to be preferentially chosen to test its association with Nocardia strain A11 and Streptomyces strains A06, A09 and A10. As the strain Streptomyces A18 already was identified at the genotypic level, it would initially be chosen to test in consortium with the Bradhyrhizobium R10 as inoculants for cowpea bean in an environmentally controlled room and later under field conditions.

The effect in vitro and under field conditions of actinobacterial strains on the growth of strains of rhizobia was reported by Htwe et al. (2018ab), Htwe and Yamakawa (2015), Xuyen et al. (2016) and Sahur et al. (2018) and the results indicated that the bacterial pairs can be useful as effective inoculants in the future.

In pioneering work, Jesus (2013) evaluated the metabolic compatibility among nine actinobacteria strains that degrade humus and six diazotrophic bacterial strains from the culture collection of the State University in Rio de Janeiro, Brazil. The author used the same method of this work and observed that $44 \%$ of the pairs were compatible (44.4\%). The lower percentage compared to the present work may be due to the greater chemical complexity of humus in relation to cellulose.

It is important to emphasize that the present study provided a better understanding of the interactions between actinobacteria and rhizobia in semiarid soils, which may be a key to developing strategies for manipulating these microbial communities, with agricultural and environmental implications.

\section{Conclusions}

In vitro cross-feeding between actinobacteria and rhizobia strains from semiarid environment proved to be an effective tool for selection bio inoculants.

\section{References}

Alexandre, A., \& Oliveira, S. (2013). Response to temperature stress in rhizobia. Critical Reviews in Microbiology, 39, 219-228. https://doi.org/10.3109/1040841X.2012.702097

Basak, K., \& Majumdar, S. K. (1973). Utilization of carbon and nitrogen sources by Streptomyces kanamyceticus for kanamycin production. Antimicrobial Agents and Chemotherapy, 4(1), 6-10. https://doi.org/10.1128/ AAC.4.1.6

Bhargava, Y. J., Murthy, S. R. T., Kumar, V. R., \& Rao, M. N. (2016). Phenotypic, stress tolerance and plant growth promoting characteristics of Rhizobial isolates from selected wild legumes of semiarid region, Tirupati, India. Advances in Microbiology, 6, 1-12. https://doi.org/10.4236/aim.2016.61001

Bronstein, J., L. (2009). The evolution of facilitation and mutualism. Journal of Ecology, 97, 1160-1170. https://doi.org/10.1111/j.1365-2745.2009.0156.x

Chen, P. J., Wei, T. C., Chang, Y. T., \& Lin, L. P. (2004). Purification and characterization of carboxymethyl cellulase from Sinorhizobium fredii. Botanical Bulletin Academia Sinica, 45(2), 111-118.

Clark, F. E. (1965). Actinomyces. In C. A. Black (Ed.), Methods of soil analysis (pp. 1498-501). American Society of Agronomy, Madison. 
Cuesta, G., García-de-la-Fuente, R., Abad, M., \& Fornes, F. (2012). Isolation and identification of actinomycetes from a compost-amended soil with potential as biocontrol agents. Journal of Environmental Management, 95, S280-S284. https://doi.org/10.1016/j.jenvman.2010.11.023

Cunha, B. B., \& Araújo, R. C. P. (2014). Avaliação das pressões e ameaças ambientais sobre o Parque Nacional de Ubajara-Ceará: Uma perspectiva da efetividade de gestão. REDE-Revista Eletrônica do Prodema, 8(1), 46-66.

Damirgi, S. M., \& Johnson, H. W. (1966). Effect of soil actinomycetes on strains of Rhizobium japonicum. Agronomy Journal, 58(2), 223-224. https://doi.org/10.2134/agronj1966.00021962005800020032x

Divito, G. A., \& Sadras, V. O. (2014). How phosphorus, potassium and sulphur affect plant growth and biological nitrogen fixation in crop and pasture legumes? Field Crop Research, 156, 161-171. https://doi.org/10.1016/j.fcr.2013.11.004

D’Souza, G., Shitut, S., Preussger, D., Yousif, G., Waschina, S., \& Kos, C. (2018). Ecology and evolution of metabolic cross-feeding interactions in bacteria. Nat. Prod. Rep., 35(5), 455-488.

Foo, E. L., \& Varma, A. K. (1976). Inhibitory effect of Streptomyces antibioticus and other microorganisms on Rhizobium. Folia Microbiologica, 21(4), 315-319. https://doi.org/10.1007/BF02876909

Graham, P. H. (1992). Stress tolerance in Rhizobium and Bradyrhizobium, and nodulation under adverse soil conditions. Canadian Journal of Microbiology, 38, 475-484. https://doi.org/10.1139/m92-079

Gregor, A. K., \& Klubek, B., Varsa, E. C. (2003). Identification and use of Actinomycetes for enhanced nodulation of soybean co-inoculated with Bradyrhizobium japonicum. Canadian Journal of Microbiology, 49(8), 483-491. https://doi.org/10.1139/w03-061

Gupta, G., Parihar, S. S., Ahirwar, N. K., Snehi S. K., \& Singh, V. (2015). Plant growth promoting rhizobacteria (PGPR): current and future prospects for development of sustainable agriculture. Journal of Microbial Biochemical and Technology, 7(2), 096-102. https://doi.org/10.4172/1948-5948.1000188

Hankin, L., \& Anagnostakis, S. L., (1977). Solid media containing carboxy methylcellulose to detect cellulase activity of microorganisms. Journal of General Microbiology, 98, 109-115. https://doi.org/10.1099/ 00221287-98-1-109

Htwe, A. Z., \& Yamakawa, T. (2015). Enhanced plant growth and/or nitrogen fixation by leguminous and non-leguminous crops after single or dual inoculation of Streptomyces griseoflavus $\mathrm{P} 4$ with Bradyhizobium strains. African Journal of Biotechnoogy, 9(49), 2337-2344. https://doi.org/10.5897/AJMR2015.7796

Htwe, A. Z., Moh, S. M., Moe, K., \& Yamakaw, T. (2018a). Effects of co-inoculation of Bradyrhizobium elkanii BLY3-8 and Streptomyces griseoflavus P4 on Rj4 soybean varieties. Soil Science and Plant Nutrition, 64(4), 449-454. https://doi.org/10.1080/00380768.2018.1452574

Htwe, A. Z., Moh, S. M., Moe, K., \& Yamakaw, T. (2018b). Effects of co-inoculation of Bradyrhizobium japonicum SAY3-7 and Streptomyces griseoflavus P4 on plant growth, nodulation, nitrogen fixation, nutrient uptake, and yield of soybean in a field condition. Soil Science and Plant Nutrition, 64(2), 222-229, https://doi.org/10.1080/00380768.2017.1421436

IBAMA (Instituto Brasileiro do Meio Ambiente e Recursos Naturais Renováveis). (2006). Plano operativo de prevenção e combate aos incêndios florestais do Parque Nacional de Ubajara.

Jesus, J. A. (2013). Potencial biotecnológico de actinobactérias e bactérias diazotróficas endofiticas para o crescimento de plantas (Master's thesis, Universidade Estadual do Norte Fluminense Darcy Ribeiro, Campos do Goytacazes, Rio de Janeiro, Brazil). Retrieved from http://www.uenf.br/Uenf/Downloads/ PRODVEGETAL_3434_1375985748.pdf

Jimenéz-Zurdo, J., Mateos, P. F., Dazzo, F. B., \& Martínez-Molina, E. (1996). Cell-bound cellulase and polygalacturonase production by Rhizobium and Bradyrhizobium species. Soil Biology and Biochemistry, 28, 917-921. https://doi.org/10-1016/0038-0717(96)00059-4

Kavamura, V. N., Taketani, R. V., Lançoni, M. D., Andreote, F. D., Mendes, R., \& de Melo, I.S. (2013). Water regime influences bulk soil and rhizosphere of Cereus jamacaru bacterial communities in the Brazilian Caatinga Biome. PLoS ONE, 8(9), 1-10. https://doi.org/10.1371/journal.pone.0073606

Koskey, G., Mburu, S. W., Njeru, E. M., Kimiti, J. M., Ombori, O., \& Maingi, J., M. (2017). Potential of native Rhizobia in enhancing nitrogen fixation and yields of climbing beans (Phaseolus vulgaris L.) in contrasting environments of eastern Kenia. Frontiers in Plant Science, 8, 1-12. https://doi.org/10.3389/flps.2017.00443 
Kulkarni, S., \& Nautiyal, C. S. (2000). Effects of salt and pH stress on temperature-tolerant Rhizobium sp. NBRI330 nodulating Prosopis juliflora. Current Microbiology, 40(4), 221-226. https://oi.org/10.1007/ s002849910045

Lima, J. V. L., Martins, S. C. S., Siqueira, K. A., Soares, M. A., \& Martins, C. M. (2017). Characterization of actinobacteria from the semiarid region, and their antagonistic effect on strains of rhizobia. African Journal of Biotechnology, 16(11), 499-507. https://doi.org/10.5897/AJB2016.15724

Marulanda, A., Porcel, R., Barea, J. M., \& Azcon, R. (2007). Drought tolerance and antioxidant activities in lavender plants colonized by native drought tolerant or drought-sensitive Glomus species. Microbial Ecology, 54, 543-552. https://doi.org/10.1007/s00248-007-9237-y

Marulanda, A., Barea, J. M., \& Azcon, R. (2009). Stimulation of plant growth and drought tolerance by native microorganisms (AM Fungi and Bacteria) from dry environments: Mechanisms related to bacterial effectiveness. Journal of Plant Growth Regulation, 28, 115-124. https://doi.org/10.5958/2229-4473.2016. 00022.7

Mueller, J. G., Skipper, H. D., Shipe, E. R., Grimes, L. W., \& Wagner, S. C. (1988). Intrinsic antibiotic resistance in Bradyrhizobium japonicum. Soil Biology and Biochemistry, 20(6), 879-882. https://doi.org/10.1016/ 0038-0717(88)90097-1

Naamala, J., Jaiswal, S. K., \& Dakora, F. D. (2016). Antibiotics resistance in rhizobium: Type, process, mechanism and benefit for agriculture. Current Microbiology, 72(6), 804-816. https://doi.org/10.1007/ s00284-016-1005-0

Obaton, M. M. (1971). Use of spontaneous mutants resistant to antibiotics for the ecological study of Rhizobium. Comptes Rendus des Séances de l'Académie des Sciences. Série D, Sciences Naturelles, 272(20), 2630-2633. https://doi.org/10.2307/20111558

Parmar, N., \& Dufresne, J. (2011). Beneficial interactions of plant growth promoting rhizosphere microorganisms. In A. Singh, N. Parmar, \& R. C. Kuhad (Eds.), Bioaugmentation, Biostimulation and Biocontrol. Soil Biology, 28 (pp. 27-42). Springer, Berlin. https://doi.org/10.1007/978-3-642-19769-7_2

Patel, J. J. (1974). Antagonism of actinomycetes against Rhizobia. Plant Soil, 41(2), 395-402. https://doi.org/ 10.1007/BF00017266

Pereira, J. C., Neves, M. C. P., \& Drozdowicz, A. (1999). Influência da antibiose exercida por actinomicetos às estirpes de Bradyrhizobium spp., na nodulação da soja. Pesquisa Agropecuária Brasileira, 34(1), 99-108. https://doi.org/10.1590/S0100-204X1999000100014

Pereira, P., Ibanez, F., Rosenblueth, M., Etcheverry, M., Martinez-Romero, E. (2011). Analysis of the bacterial diversity associated with the roots of Maize (Zea mays L.) through culture-dependent and culture-independent methods. International Scholarly Research Network, 1-10. https://doi.org/10.5402/ $2011 / 938546$

Pikovskaya, R. I. (1948). Mobilization of phosphorous in soil in connection with vital activity of some microbial species. Mikorobiologiya, 17, 362-370

Priyadarshini, A., Singdevsachan, S. K., Tripathy, S. K., Mohanta, Y. K., Patra, J. K., \& Sethi, B. K. (2016). British Biotechnology Journal, 12(2), 1-3. https://doi.org/10.9734/BBJ/2016/24102

Pugashetti, B. K., Angle, J. S., \& Wagner, G. H. (1992). Soil microorganism antagonistic towards Rhizobium japonicum. Soil Biology and Biochemistry, 14, 45-47. https://doi.org/10.1016/0038-0717(82)90075-X

Rassem, A. M., \& David, A. A. (2017). In vitro evaluate antagonism strains of Actinomycetes on growth strains of Rhizobium. World Journal of Pharmacy and Pharmaceutical Sciences, 6(3), 894-903. https://doi.org/ 10.20959/wjpps20173-8775

Robledo, M., Jimenez-Zurdo, J. I., Velázquez, E., Trujillo, M. E., Zurdo-Pineiro, J. L., Ramírez-Bahena, M. H., ... Mateos, P. F. (2008). Rhizobium cellulase $\mathrm{CelC}_{2}$ is essential for primary symbiotic infection of legume host roots. Proceedings of the National Academy of Sciences PNAS, 105(19), 7064-7069. https://doi.org/10.7003/pnas.0802547105

Russel, J., Rødera, H. L., Madsena, J. S., Burmøllea, M., \& Sørensen, S. J. (2017). Antagonism correlates with metabolic similarity in diverse bacteria. PNAS, 114(40), 10684-10688. https://doi.org/10.1073/pnas.17060 16114 
Sahur, A., Ala, A., Patandjengi, B., \& Syam'un, E. (2018). Effect of seed inoculation with actinomycetes and rhizobium isolated from indigenous soybean and rhizosphere on nitrogen fixation, growth, and yield of soybean. International Journal of Agronomy, 2018, 1-7. https://doi.org/10.1155/2018/4371623

Saini, A., Aggarwal, N. K., Sharma, A., \& Yadav, A. (2015). Actinomycetes: A source of lignocellulolytic enzymes. Enzyme Research, 2015, 1-15. https://doi.org/10.155/2015/279381

Seishiro, A., Motomi, I, \& Wataru, I. (2013). From B- to ó-Proteobacteria: The origin and evolution of Rhizobial nodulation Genes nodIJ. Molecular Biology and Evolution, 30(11), 2494-2508. https://doi.org/10.1093/ molbev/mst153

Seth, E. C., \& Taga, M. E. (2014). Nutrient cross-feeding in the microbial world. Frontiers in Microbiology, 5, 1-6. https//doi.org/10.3389/fmicb.2014.00350

Shirling, E. B., \& Gottlieb, D. (1966). Methods for characterization of Streptomyces species. International Journal of Systematic Bacteriology, 13, 313-340. https://doi.org/10.1099/00207713-16-3-313

Sierra, G. (1957). A simple method for the detection of lipolytic activity of micro-organisms and some observations on the influence of the contact between cells and fatty substrates. Antonie van Leeuwenhoek, 23(1), 15-22. https//doi.org/10.1007/BF02545855

Sinaj, S., Buerkert, A., El-Hajj, G., Bationo, A., Traoré, H., \& Frossard, E. (2001). Effects of fertility management strategies on phosphorus bioavailability in four West African soils. Plant and Soil, 233, 71-83. https://doi.org/10.1023/A:1010314108931

Soe, K. M., Bhromsiri, A., \& Karladee, D. (2012). Effects of selected endophytic actinomycetes (Streptomyces sp.) and bradyrhizobial from Myanmar on growth, nodulation, nitrogen fixation and yield of different soybean varieties. Soil Science and Plant Nutrition, 9, 95-10 https:// doi.org/10.1080/00380768.2012.682044

Soe, K. M., \& Yamakawa, T. (2016). Low-density co-Inoculation of Myanmar Bradyrhizobium yuyanmingense MAS34 and Streptomyces griseoflavus P4 to enhance symbiosis and seed yield in soybean varieties. American Journal of Plant Science, 7, 1652-1661. https://doi.org/10.4236/ajps.2016.712156

Stadie, J., Gulitz, A., Ehrmann, M. A., \& Vogel, R. F. (2013). Metabolic activity and symbiotic interactions of lactic acid bacteria and yeasts isolated from water kefir. Food Microbiology, 35, 92-98. https://doi.org/ 10.1016/j.fm.2013.03.009

Tasia, Y. W., \& Melliawati, R. (2017). Cellulase and xylanase production from three isolates of indigenous endophytic fungi. IOP Conf. Series: Earth and Environmental Science, 101, 1-8.

Tiwari, K., \& Gupta, R. K. (2012). Rare actinomycetes: A potential storehouse for novel antibiotics. Critical Reviews in Biotechnology, 32, 108-113. https://doi.org/10.3109/07388551.2011.562482

Tole, S. B., Fawade, M. M., \& Patil S. M. (2016). Amylase activity of a starch degrading bacteria isolated from soil around Tulja-Bhavani Temple of Tuljapur. Journal of Pharmacy and Biological Sciences, 1-6. https://doi.org/ 10.9790/3008-1106020106

Torres-Júnior, C. V., Leite, J., Santos, C. E. R. S., Fernandes-Júnior, P. I., Zilli, J. E., Rumjanek, N. G., \& Xavier, G. R. (2014). Diversity and symbiotic performance of peanut rhizobia from Southeast region of Brazil. African Journal of Microbiology Research, 8(6), 566-577. https://doi.org/10.5897/AJMR2013.5883

Van Schreven, D. A. (1964).The effect of some actinomycetes on rhizobia and Agrobacterium radiobacter. Plant and Soil, 21, 283-302. https://doi.org/10.1007/BF01377745

Vieira, R. M. S. P., Tomasella, J., Alvalá, R. C. S., Sestini, M. F., Affonso, A. G., Rodriguez, D. A., ... Santana, M. O. (2015). Identifying areas susceptible to desertification in the Brazilian northeast. Solid Earth, 6, 347-360. https://doi.org/10.5194/se-6-347-2015

Vincent, J., M. (1970). Manual for the practical study of root nodule bacteria. Oxford: Blackwell Scientific Publications.

Wink, J. M. (2012). Compendium of actinobacteria. Methods for the taxonomic description of the Actinobacteria. Braunschweig University of Technology, Braunschweig.

Wintermute, E. H., \& Silver, P. A. (2010). Emergent cooperation in microbial metabolism. Molecular Systems Biology, 6(407), 1-7. https://doi.org/10.1038/msb.2010.66 
Xuyen, H. L., Franco, C. M. M., Ballard, R. A., \& Drew, E. A. (2016). Isolation and characterisation of endophytic actinobacteria and their effect on the early growth and nodulation of Lucerne (Medicago sativa L.). Plant Soil, 405, 13-24. https://doi.org/10.1007/s11104-015-2652-9

Zilli, E., Valisheski, R. R., Freire Filho, F. R., Neves, M. C. P., \& Rumjanek, N. G. (2004). Assessment of cowpea rhizobium diversity in Cerrado areas of northeastern Brazil. Brazilian Journal of Microbiology, 35, 281-287. https://doi.org/10.1590/S1517-83822004000300002

\section{Copyrights}

Copyright for this article is retained by the author(s), with first publication rights granted to the journal.

This is an open-access article distributed under the terms and conditions of the Creative Commons Attribution license (http://creativecommons.org/licenses/by/4.0/). 